Białoruski Panstwowy Uniwersytet Ekonomiczny

Mińsk

https://orcid.org/0000-0002-8066-4207

\title{
Рэканструкцыя архетыпа як сродак спасціжэння аўтарскага несвядомага (на прыкладзе твораў Максіма Гарэцкага вяцкага перыяду)
}

Паняцце архетып увайшло у у навуковы дыскурс $\ddot{\mathrm{y}}$ XIX стагоддзі праз даследаванні англійскага заолага Рычарда Оўэна, аднак трывала замацавалася як тэрмін толькі ў працах швейцарскага псіхолага Карла Густава Юнга ў першай палове XX стагоддзя.

Асобныя ідэі дактрыны Юнга аказалі шырокі ўплыў на характар літаратуразнаўчых даследаванняў прадстайнікой рытуальна-міфалагічнай літаратурнай крытыкі, сярод якіх былі Н. Фрай і М. Бодкін. Так, канадскі літаратуразнаўца Н. Фрай упершыню прымяніӱ у літаратуразнаўстве даследаванне Юнга пра калектыўнае несвядомае, што расчытваецца праз архетыпы, і выклаў свае першыя ідэі ў эсэ "Архетыпы літаратуры", якое папярэднічала яго асноўнай працы на гэту тэму "Анатомія крытыкі". Як адзначае Е. Меляцінскі: Фрай разглядае міф, архетып, рытуал не як крынічу, а як сутнасць паэтычнага (у сэнсе - мастацкага) твора (...) Фрай выкарыстоўвае сімвалізм Бібліі $і$ грэчаскай міфалогіi для канструявання "граматыкі літаратурных архетыпаў”. Англійскі даследчык М. Бодкін, па словах Е. Меляцінскага, прапаноўваў наступную гіпотэзу: Meтафары, nа сутнасиі, пастаянныя, паэзія нам дае вынікі эмачьянальнага жьиця, але жыиия звышперсанальнага, г. зн. якое ўзыходзіць да калектыўна-несвядомага. Яно вывучае ў міфах пераходы ад жьиця да смериі $і$ ад смериі да

1 Е. Мелетинский, От мифа к литературе. Курс лекций "Теория мифа и историческая поэтика", Москва 2000, с. 22. 
жыция, иікавічча сімваламі саячтва, вобразамі боскага, дэманічнага $i$ гераічнага ${ }^{2}$.

Такім чынам паняцце архетып заняло сваё месца ў літаратуразнаўстве. У 90-я гады XX стагоддзя вывучэнне уззаемасувязі міфа і літаратуры выклікае асаблівую цікавасць. Над пытаннем, чаму менавіта ў гэты гістарычны адрэзак часу сфарміравалася такая цікавасць да міфалогіі разважае Таццяна Шамякіна: Узрастае иікавасць да духойных праблем, да таямніч чалавечай псіхікі, а таксама адчуваециа тэндэнцыя набліжэння адна да адной навукі і рэлігіi. Апошняя тэндэнцыля, магчьма, стане вызначальнай менавіта ў XXI $\mathrm{cm} .^{3}$

Так і сталася: XXI стагоддзе спарадзіла асаблівую цікавасць даследчыкаў да актуалізацыі архетыпа ў мастацкім творы. Поруч з метадалогіяй культурна-гістарычнага і кампаратыўнага літаратуразнаўства даследчыкі актуалізавалі традыцыі міфалагічнай школы. Новую ўвагу прыцягнуй іншы ӱзровень успрыняцця літаратуры: неабходнасць разгледзець згорнуты тэкст (не падтэкст -. . Г.) унутры самога мастацкага тэксту.

Для ілюстрацыі вышэй акрэсленай думкі супаставім ідэі двух выбітных беларускіх літаратуразнаўцаў. Т. Шамякіна сцвярджае: Многія пісьменнікі мадэлявалі і мадэлюючь рэчаіснасць паводле законаў міфалагічнага мыслення ${ }^{4}$. Пятро Васючэнка выказвае падобнае назіранне: Літаратары канструююиь не толькі лёсь иыьвілізацылі, але i свае йласныля - праз тэкстьи ${ }^{5}$.

На фоне даследавання літаратуры ў гістарычнай (рэальнай) прасторы і гістарычным часе фарміруецца тэндэнцыя вывучыць твор у межах унутрылітаратурнай прасторы, неабходнасць убачыць у творы прыватнае, асабістае, "нясвецкае" жыццё самога пісьменніка, яго ўтоеныя эмоцыі, яго "неафіцыйную" філасофію. Вось тут актуалізацыя архетыпа як адбітку пісьменніцкага несвядомага дазволіць убачыць сапраўднае “я" творцы і расчытаць у творы яго "alter" ідэю.

Творчасць Максіма Гарэцкага 1930-х гадой якраз той выдатны матэрыял, праз які мы можам прадэманстраваць, як даследаванне архетыпай, што актуалізуюцца у творы, дапамагае ўбачыць утое-

2 Тамсама, с. 22.

3 Т. Шамякіна, Міфалогія $i$ беларуская літаратура: нарысы $i$ эсэ, Мінск 2008, c. 8 .

4 Тамсама, с. 10.

5 П. Васючэнка, Ад тэксту да хранатопа, Мінск 2009, с. 190. 
ны змест тэксту, так бы мовіць, расчытаць тую інфармацыю, якую палітычная цэнзура 1930-х гадоў убачыць (у сілу розных абставін) не магла.

1930-я гады у жыцці М. Гарэцкага - не самы спрыяльны час для творчасці. У 1931 годзе ён знаходзіўся ў мінскай турме ў якасці абвінавачанага ў прыналежнасці да нелегальнай контррэвалюцыйнай арганізацыі, а ў красавіку гэтага ж года быў сасланы на пяць гадоў у Вятку па сфабрыкаванай справе СВБ. Там ён працуе на раманам "Віленскія камунары", спрабуе дапісаць "Камароўскую хроніку", а таксама аўтабіяграфічныя творы "Лявоніус Задумекус" і “Скарбы жыцця" (апошнія, на жаль, засталіся незавершанымі). Актуалізацыі архетыпаў у творах "Віленскія камунары" і "Лявоніус Задумекус" і будзе прысвечана наша ўвага.

Філасофска-алегарычны твор "Лявоніус Задумекус" даваўся пісьменніку не вельмі лёгка. Я пісаў пра Задумекуса, ды пакуль што адлажыў, бо не пішациа так, як хочаииа 6 , - шчыраваў пісьменнік у лістах да жонкі Леанілы Усцінаўны. Відавочна, што ён жадае апісаць сваё ўласнае адчуванне рэчаіснасці, раскрыць душэўны боль ад пачуцця несправялівасці, аднак гэта немагчыма было зрабіць у адкрытай дзённікавай форме з-за цэнзуры, у тым ліку ўнутранай. Менавіта па гэтай прычыне пісьменнік (канкрэтны аўтар) не дэманструе нам вобраз апавядальніка (наратара), не афармляе яго як нейкі мастацкі тып. Пры гэтым у чытача ӱзнікае адчуванне, што апавядальнік у нейкім сэнсе прарок, дэміург, які вядзе дыялог з чытачом у паводлебіблейскай манеры, нібы аднекуль зверху, з вышыні перажытага прадракаючы яго жыццё. Наратар звяртаецца да чытача на "ты", што адразу змяншае дыстанцыю паміж імі: Будзеш тьл стаяць, будзеш чакаць, хатьлі свае на дол спусиіш. I будзеш ты ияпер вель-

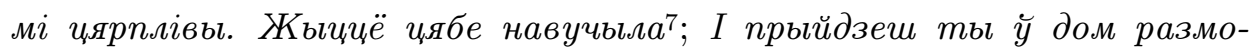
вы на адлегласиі, каб пачуць там блізкі голас (473); Будзеш ты ляжаць на падлозе як сабака (474). Месцамі наратар звяртаеца да адрасата і называе яго імя: Успомні, уздумай, прыгадай сабе, Лявоніус Янус, як сядзеў ты уั страшнай вежь, з забаронаю глядзець у вакно, $i$ здалёк бачьў работу на пабудове (500); часам дае ўласныя прозвішчы - "блазенны", “блазенны імпатэнт цёмналескі". Стыль апо-

\footnotetext{
6 М. Гарэцкі, Творы: Дзве душы: Аповесць. Апавяданні. Жартаўлівы Пісарэвіч: П'еса. Літаратурная крытыка і пубіџыстыка, Мінск 1990, с. 436.

7 М. Гарэцкі, Выбраныл творыл, Мінск 2009, с. 472. Далей пры спасылцы на гэта выданне $\breve{y}$ дужках падаецца старонка.
} 
веду месцамі мяняецца, і замест маналогу, аформленага $\ddot{y}$ будучым часе, чытач можа сутыкацца 3 нарацыяй-травелогам, дзе фіксуюцца дзеянні самога Лявоніуса Задумекуса: Піша Лявоніус (Мізэрыуус) адказную эпістолію Цярплівай Ласцьл.. I піша Лявоніус паведамленне иёмналескаму дубу і белай бярозиьл.. (473); Блазеннь спьняециа, каўнер паставіў, рукі рукаў у рукаў, стаіць разважае.. (507). Такая варыятыўнасць нарацыі тлумачыцца, па-першае, незавершанасцю твоpa, па-другое, эмацыйнасцю рэальнага пісьменніка, які ў момант напісання твора перажываў вялікія жыццёвыя катастрофы. Зразумела, што ён ставіў за мэту апісаць гісторыю жыцця "блазеннага імпатэнта цёмналескага", Лявоніуса Задумекуса (= Мізэрыуса Монуса, Лявоніуса Януса). Аднак жаданне як мага хутчэй выказацца пра тыя цяжкасці, якія сустрэнуцца на шляху персанажа, змяняе структуру сюжэта, і замест гісторыі жыцця Лявоніуса Задумекуса мы атрымліваем своеасаблівы “травелог у перспектыве”, аформлены ў асаблівай аўтарскай стылістыцы.

Дамінанта паўтораў "І будзеш ты...", "I пойдзеш ты...", "I падумаеш ты..." нагадвае стылістыку рэлігійнага дыскурсу , дзе у павучальнай, размеранай манеры распавядаецца пра этапы і заканамернасці жыцця. У нашым выпадку наратар, з улікам свайго жыццёвага досведу, распавядае чытачу пра перспектывы будучыні, наканавання. Узнікае адчуванне, што ён, добра ведаючы абстрактнага чытача, яго лёс і патрэбы, чытае пропаведзь. Часам думаецца, што наратар распавядае пра сябе, таму што вельмі падрабязна апісвае перспектыву жыцця свойму адрасату. I гэта не выпадковае адчуванне, бо па словах С. В. Блувберга са спасылкай на В. I. Карасіка, пропаведзь з'яўляециа “адваротным бокам" споведзі ў тылм сэнсе, ито прьи споведзі камунікатыўны вектар накіраваны уั бок Бога, а пры пропаведзі - у бок чалавека. Але $i$ ў тылм, $i$ ў іншьлм выпадку святар выступае у ролі медьцмма ${ }^{8}$.

Стыль маўлення наратара ў нейкай ступені падобны да стылістыкі "Нагорнай пропаведзі Ісуса Хрыста", і гэта лішні раз падкрэслівае, што наратар у творы выступае $\breve{y}$ якасці медыума, які набліжаны да нечага сакральнага, валодае звышінфармацыяй. Па сваім характары ён нагадвае персанажа трансфармаванага тыпу, які прыйшой да сакральнага праз нейкі грэшны вопыт.

8 С. Блувберг, Религиозный дискурс, "Социальная политика и социология" 2007, № 2, с. 228. 
Можна выказаць меркаванне аб актуалізацыі $\ddot{y}$ творы архетыпа "раскаянага грэшніка", прадстаўленага пэўнай сюжэтнай схемай, якую Ю. М. Лотман акрэслівае як злачынства (сапраўднае иі ўяўнае) - высылка ў Сібір - уваскрасенне ${ }^{9}$. Гэтую сюжэтную схему даследчык выкарыстойвае ӱ дачыненні да рускага рамана XIX стагоддзя (да творчасці Тургенева, Дастаеўскага, Гогаля). Але яна адмыслова стасуецца і з творам беларускага класіка М. Гарэцкага "Лявоніус Задумекус". Так, Ю. М. Лотман адзначае: Тут персанаж "выратавальнік" стульваеица з персанажам, місія якога - у пераробцы сваёй уласнай сутнасці. Сюжэт гэты выразна аднаўляе міф пра грэшніка, які дайшоў да апагею злачынстваў $і$ стаў пасля маральнага крызісу святылм (Андрэй Крыџкі, баџька Рыгор і інш.), і пра смерць героя, сыходжанне яго y̆ пекла $і$ новае адраджэнне ${ }^{10}$.

Калі звязаць гэтую думку з творам М. Гарэцкага, то можна ўбачыць наступнае: наратар-выратавальнік дэманструе пазіцыю пісьменніка, вымушанага пад канец жыцця пераасэнсаваць сваю сістэму каштоўнасцей, змірыцца з наканаванасцю лёсу. Менавіта таму наратар выступае ў ролі месіі, які цану рэчам пазнаў. Людзей да самых гльббінь уведаў. Жиъциём даражыць навучыйся... (550). Прадстаўнікі сталінскай сістэмы абвясцілі пісьменніка ворагам народа, па сутнасці, зрабілі злачынцам часу. Яго знаходжанне ў Сібіры было тым пеклам, 3 якога ўжо было немагчыма ўзняцца. Прайшоўшы ўсе магчымыя выпрабаванні, якія стварала сістэма на шляху варожага для дзяржаўнай ідэалогіi літаратара, пісьменнік "адрадзіўся нанова", атрымаў свой досвед душэўнага змірэння і прыняцця існага быцця: Ж ыицё трэба ведаџь з усіх бакой. Можа, яно так, можа, не зусім. Падумаеш потылм (490). Менавіта таму маўленне наратара і набліжана да пропаведзі.

У развагах М. Ю. Лотмана пра міфалагему "раскаянага грэшніка" ёсць вельмі тонкая заўвага:

Злачынца мог апынуцца ўяўным злачынцам, злачынцам у вачах злачыннага грамадства, ахвярай, узяць на сябе чужую віну і г.д. Важна, што ва ўсіх гэтых выпадках сустрэча з некаторым "настаўнікам жыцця", прасвятленне, ператварэнне героя адбываюцца менавіта пасля яго грамадзянскай смерці і лакальна звязваюцца з Сібірру. У гэтых адносінах характэрны міф пра Фёдара Кузміча [Фёдар Кузьміч - старац, які жыў

9 Ю. Лотман, В школе поэтического слова, Москва 1988, с. 338.

10 Тамсама, с. 338. 
у Сібіры ў XIX ст. Існуе легенда, быццам бы гэта быў імператар Аляксандр I, які інсцэніраваў сваю смерць і стай скітальнікам - В.Г.]. У сюжэце адсутнічае канкрэтнае злачынства, якое заменена ўсведамленнем злачыннасці ўсяго жыцця як такога, як часта ў міфалагічных і міфа-казачных тэкстах рэальная смерць пазначана падменай. Але вельмі паказальна менавіта для рускага варыянту, што - і пры адсутнасці высылкі або катаргі - уваскрасенне адбываецца менавіта ў Сібіры ${ }^{11}$.

Апісаны феномен "уяўнага злачынства" як найлепей падыходзіць да гісторыі жыцця Лявоніуса Задумекуса, унутрытэкставага прадстайніка айтара. Апавядач з'яйляецца ўяўным злачынцам: у сюжэце твора няма апісання канкрэтнага ўчынку, што прывёў да бяды, дзеянне адразу адбываецца ў Сібіры, дзе персанаж твора адбывае пакаранне. За што пакараны Лявоніус Задумекус - чытачу не вядома, аднак апавядальнік дае нам падказку: I апостал Навум доўга сядзеў у иямніцьл, а потылм падверглі яго баніцыі $і$ астракізму (521). Апеляцыя да асобы прарока Навума, вядомага як заступніка людзей разумовай працы, не выпадковая. Як вядома, Старазапаветная кніга прарока Навума змяшчае прадказанне гібели асірыйскага горада Ніневіі праз беззаконне, якое адбывалася ў ім. Выкажам меркаванне, што пісьменнік праз наратара спрабуе правесці паралель паміж асірыйскім мінулым і тагачаснай савецкай рэчаіснасцю, падчас якой з патрыёта быў ператвораны ў ворага народа і вымушаны быў адчуваць сябе "раскаяным грэшнікам" і прыводзіць да думкі, што любая імперыя калі-небудзь падзе праз беззаконне і несправядлівасць.

У гэты ж перыяд М. Гарэцкі працуе над раманам "Віленскія камунары", у якім таксама актуалізуецца архетып, толькі не пакутлівага "раскаянага грэшніка", а авантурнага, жвавага, а часам і смешнага “трыкстара". Варта падкрэсліць, што нягледзячы на тое, што творы, пра якія вядзецца гаворка $\breve{y}$ артыкуле, пісаліся прыблізна ў адзін час, у рамане пісьменнік усё ж стварае канкрэтны вобраз наратара - Мацея Мышкі. Адразу паўстае пытанне: чым выклікана адсутнасць канкрэтнага вобраза наратара $\ddot{y}$ адным творы і яго яскравая, дынамічная прысутнасць у другім? Тут варта звярнуцца да раскрыцця сутнасці архетыпа "трыкстара".

Т. Шамякіна таксама сцвярджае, што

міфалагічны трыкстар - далёкі папярэднік сярэднявечных блазанаў, махлярой, хітруганаў, герояў авантурна-махлярскіх раманаў, розных ка-

11 Ю. Лотман, В школе поэтического слова, с. 340. 
мічных двайнікоў. (...) У беларускай літаратуры рысы трыкстараў маюць багі у травесційных паэмах "Энеіда навыварат" і "Тарас на Парнасе" (XIX ст.); да трыкстара падобны Кручкой з "Пінскай шляхты" Вінцэнта Дуніна-Марцінкевіча (XIX ст.), а Юрась Братчык з рамана "Хрыстос прызямліўся у Гародні" Уладзіміра Караткевіча (XX ст.) выяўляе сябе то як культурны герой, то як трыкстар ${ }^{12}$.

Відавочна, што феномен трыкстара зафіксаваны ӱ авантурных раманах. Гэты вобраз прыйшоў у літаратуру з міфалогіi, па сутнасці сваёй ён з'яўляецца супрацьлеглым вобразу культурнага героя, таго міфічнага персанажа, які прымае непасрэдны ўдзел у стварэнні свету, а потым і ва ўладкаванні жыцця. Е. Меляцінскі адзначае:

Дэманічна-камічнаму дублёру культурнага героя надаюцца рысы прайдзісвета-гарэзы (трыкстара). Культурныя героі часта карыстаюцца хітрым штукарствам дзеля дасягнення поспеху ў самых сур'ёзных справах (так Праметэй падманвае багой пры дзяльбе мяса) (...) У тыпе трыкстара быццам бы заключаны нейкі ӱніверсальны камізм, які распаўсюджваецца і на абдураных ахвяр прайдзісвета, і на высокія рытуалы, і на асацыяльнасць і нястрыманасць самога прайдзісвета... ${ }^{13}$.

\section{Ю. Лотман прыходзіць у сваіх разважаннях да высновы, што}

розныя гістарычныя эпохі і тыпы культуры вылучаюць розныя падзеі, асобы і тэксты як міфагенныя. Найбольш выразнай (хоць і найбольш знешняй) прыкметай такой міфанараджаючай ролі з'яўляецца ўзнікненне цыклаў тэкстаў, якія распадаюцца на ізаморфныя эпізоды, якія маюць магчымасць нарошчвацца. Міфалагічная сутнасць падобных тэкстаў у тым, што абраны імі герой аказваецца дэміургам пэўнага ўмойнага свету, які, аднак, навязваецца аўдыторыі ў якасці мадэлі рэальнага свету ${ }^{14}$.

Гістарычны перыяд 1905-1917 гадоў, перыяд рэвалюцыйных перамен і з'яўляецца той міфагеннай падзеяй, якая адыграла «міфанараджаючую» ролю не толькі для беларускай, але і для уссей савецкай літаратуры. У сувязі з вышэйпрыведзеным выказваннем Ю. Лотмана можна адзначыць, што раман М. Гарэцкага «Віленскія камунары»- цыкл невялічкіх «абразкоў» (як называў іх пісьменнік), гісторый пра тое, як

\footnotetext{
12 Т. Шамякіна, Міфалогія $і$ беларуская літаратура: нарысы $і$ эсэ, с. 188-190.

13 Е. Мелетинский, Мифы народов мира: энциклопедия: в 2 m., Москва 1994, c. 26-27.

14 Ю. Лотман, История и типология русской культуры, Санкт-Петербург 2002, c. 735 .
} 
беларускаму народу даводзілася выжываць у час лёсавызначальных перамен, рэвалюцыйнай барацьбы. Нягледзячы на тое, што героя рамана М. Гарэцкага нельга ў поўнай ступені назваць «дэміургам пэўнага ўмоўнага свету», у вобразе Мацея Мышкі выразна праяўляюцца рысы культурнага архетыпа трыкстара. Аднак пры ӱжыванні паняцця «трыкстар» у дачыненні да персанажа рамана XX стагоддзя трэба добра ўсведамляць, што сувязь з міфалогіяй тут даволі ўмоўная, а само паняцце «трыкстар» дастаткова трансфармаванае, хоць у сучасным літаратуразнаўстве яно і зрабілася аператыўным.

Паняцце мае некаторыя адрозненні не толькі ад сфарміраванага $\breve{y}$ міфалогіi, замацаванага $\breve{y}$ псіхалогіi, але і ад увасобленага $\breve{y}$ авантурным рамане праз вобраз пікаро. Тут хутчэй трэба апеляваць да паняцця "савецкі трыкстар" - у пэўным сэнсе нашчадка архаічнага "трыкстара". Пра такі літаратурны тып пісаў М. Ліпавецкі, прафесар універсітэта Каларада:

Савецкі трыкстар, нягледзячы на блізкасць да махляра, усё ж такі не махляр: ад махляра ён адрозніваецца, па-першае, тым, што нават калі у яго (ці ў яе) і ёсць меркантыльны інтарэс, то ён яўна гасне перад артыстызмам і тэатральнасцю ўчынкаў героя. Па-другое, - i гэта, бадай, больш важна, - пікаро, як правіла, залежыць ад гаспадара, і яго мабільнасць вызначаецца зменай гаспадарой, тады як трыкстар - абсалютна незалежны персанаж ${ }^{15}$.

Такім чынам, вобраз Мацея Мышкі не з'яўляецца прамым увасабленнем архетыпа трыкстара, а рэпрэзентуе яго $\ddot{\mathrm{y}}$ трансфармаваным выглядзе, прадыктаваным зменай гістарычных эпох. Мацей Мышка не махляр, не прайдзісвет, у яго няма наўмыснага жадання падмануць, скрасці або здрадзіць, а калі ён, часам, і рашаецца на дробныя, асуджальныя з пункту гледжання традыцыйнай маралі, учынкі, то робіць гэта з такой непасрэднасцю і шчырай матываванасцю, што нават не ўзнікае жадання дакараць яго. Так, у адным з эпізодаў рамана паказваецца, што Мацей забірае дровы для сугрэву, якія належалі яго бацьку, але бацька - ідэалагічны вораг, меншавік; у іншым эпізодзе гаворыцца, што ён жыве з Юзяй, якая мае мужа, Ромуся Рабэйку, але пры гэтым Мышка даглядае яе сына Напалеона і дапа-

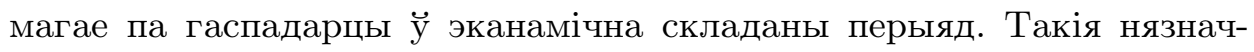

15 М. Липовецкий, Трикстер и “закрытое общество”, НЛО 2009, № 100 [online], https://magazines.gorky.media/nlo/2009/6/trikster-i-zakrytoe-obshhestvo.html, [доступ: 04.04.2020]. 
ныя, дробныя ўчынкі галоўны герой здзяйсняе на працягу ўсяго твора, пры гэтым М. Гарэцкі стварае вакол яго такую мастацкую прастору, у якой Мацей Мышка не падаецца ашуканцам, махляром, цынікам, а, наадварот, выклікае станоўчыя эмоцыі, спачуванне свайму няпростаму лёсу.

З улікам вышэйсказага можна адказаць на пытанне, чаму ў рамане "Віленскія камунары", напісаным у адзін час з творам "Лявоніус Задумекус" М. Гарэцкі стварае менавіта такі вобраз, звяртаецца менавіта да такога спосабу адлюстравання рэчаіснасці? Таму што «савецкі трыкстар», на думку М. Ліпавецкага найбольш адэкватна ўвасобіў сілу иынізму, неабходнага для выюььвання ў незразумельх $і$ непразрыстызх сацьяльныьх умовах савецкага грамадства, якія пастаянна мяняючиа, адлюстроўваючь - у камічнай, займальнай форме - тую рэальную саџыяльнасць, якая уัзнікла ў выніку бальшавічкага эксперыменту $і$ якая не уппісалася ў бінарныля структурь як афіщыийнага савецкага, так $і$ неафіиыйнага дыскурсаўํ․

М. Гарэцкі, як непасрэдны відавочца рэвалюцыйных падзей і ахвяра рэпрэсій, дакладна перадаў у рамане тую атмасферу, у якой вымушаны быў жыць. Нягледзячы на тое, што раман «Віленскія камунары» пісаўся для друку, аўтар знайшоў магчымасць не толькі перадаць дух эпохі, але і ў сацыяльна-бытавых і палітычных «абразках» стварыць такі мастацкі шматгранны вобраз, які, з аднаго боку, рэпрэзентаваў героя рэвалюцыі, а з другога боку, праз свае наіўнасць і непасрэднасць паказваў рэальную гістарычную сітуацыю, выяўляў увесь цынізм эпохі.

Такім чынам, літаратурны трыкстар савецкага часу адрозніваецца ад міфалагічнага, аднак існуюць пэўныя рысы, якія падкрэсліваюць агульную прыроду вобраза. Прымаючы пад увагу вынікі сучасных даследаванняў пра трыкстара, можна вылучыць наступныя найбольш важныя характарыстыкі, якія праяўляюцца у савецкай літаратуры: «савецкі трыкстар» амбівалентны, выконвае функцыю медыятара, ён лімінальны, схільны да тэатральнасці, прама або ўскосна звязаны з сакральным кантэкстам. У той ці іншай ступені гэтыя рысы ўласцівыя і вобразу Мацея Мышкі.

У падобным адлюстраванні гістарычных рэалій выразна адчуваецца прысутнасць дзвюх свядомасцей - свядомасці пісьменніка, сведкі рэвалюцыйных падзей, і Мацея Мышкі, героя-апавядальніка, той мас-

16 Тамсама. 
кі, якой дазволена парушаць агульнапрынятыя парадкі. Два галасы, дзве свядомасці, гарманічна ўплеценыя у гістарычны кантэкст твора - той інструмент, які зрабіў магчымым існаванне аднаго з першых савецкіх трыкстарай у беларускай літаратуры. Можна сцвярджаць, што голас М. Гарэцкага - гэта голас недалёкай паслярэвалюцыйнай гісторыі, а голас Мацея Мышкі - голас рэальнага «маленькага чалавека», народжанага $\ddot{\mathrm{y}}$ хаосе рэвалюцы і вымушанага пры гэтым жыць.

Дзякуючы элементам смехавой культуры ў рамане пэўным чынам зніжаецца і залішняя пафаснасць у адлюстраванні рэвалюцыйных падзей. Магчыма, у гэтым заключаецца адказ на пытанне: чаму М. Гарэцкі часам іранізуе і над сваім героем, і над гістарычнай сітуацыяй увогуле? Іранізуе над героем не столькі аўтар, колькі сам час, што вымушае людзей дзейнічаць нестандартна, нетрадыцыйна. Мацей Мышка спрабуе знайсці сябе $\ddot{y}$ новым жыцці, адкрыць у сабе «новага героя», пра якога так шмат пісалася ў раманах 1920-1930-х гадоў. Аднак стварыць літаратурны вобраз «новага чалавека» рэвалюцыі аказалася значна прасцей, чым сфарміраваць яго ӱ рэальным жыцці.

Мышка - дзіця рэвалюцыі, гэтым ён набліжаецца да трыкстара, бо паводзіны дзіцяці ў пэўным сэнсе падобныя да трыкстаравых. Мэта трыкстара - усведамленне сябе як асобы, пошук уласнага шляху, назапашанне вопыту, аддзяленне ад бацькоў (дарэчы, Мышка вельмі хацеў аддзяліцца ад маці і менавіта таму не надта перажываў, што трапіў у Белавежу), перадача вопыту наступным пакаленням. Усё гэта характэрна і для героя рамана М. Гарэцкага: ён шукае сябе у жыцці, перабірае палітычныя партыі, займаецца самааналізам, разважае над уласным выбарам, хай часам і прымітыўна. Ён, сапраўды, нагадвае дзіця, якое робіць першыя крокі. Але апісанне такога становішча гэта яшчэ і адлюстраванне "нясвецкага" жыцця, філасофіі ўспрыняцця рэчаіснасці і спосабу выжывання самога пісьменніка ў рэвалюцыйную пару.

Падчас высылкі ў Вятцы мы бачым іншага М. Гарэцкага: гэта ўжо філосаф, дыміург, прарок, чалавек, які “цану рэчам пазнаў”. Ён не імкнецца знайсці выйсце з ўзніклага становішча, не змагаецца за выжыванне сярод сабе падобных, не шукае лепшае вопраткі і смачнейшае ежы. Перад намі паўстае "раскаяны грэшнік". Відавочна, што "пабочны глядзеннік і ціхі думаннік" Лявон Задума перамог авантурыста i аптыміста Мацею Мышку. У гэтым факце дамінантнага архетыпа заключаецца выніковая ідэя жыццёвай філасофіі Максіма Гарэцкага: Трэба пабыць у розных становішчах, каб пазнаџь жьциё (522). 
У выніку супастаўлення двух архетыпаў, актуалізаваных у твоpax Максіма Гарэцкага вяцкага перыяду, трэба адзначыць наступнае. Важна, што сам пісьменнік, па-першае, не імкнуўся наўмысна прывязваць літаратурныя вобразы да канкрэтных архетыпаў; і па-другое, нельга сцвярджаць таксама наяўнасць у творах М. Гарэцкага ўласна архетыповых сюжэтаў. Адметнасць "Лявоніуса Задумекуса" i "Biленскіх камунараў” заключаецца у тым, што актуалізацыя ахетыпаў у згаданых творах носіць несвядомы характар. Архетыпы тут уяўляючь сабой адлюстраванне вопьту чалавецтва, які пастаянна паўтараециа ${ }^{17}$.

Гэта значыць, што пісьменнік не мадэляваў учынкі літаратурных персанажай твора свядома, падладкойваючы пад стэрэатып паводзін паводле архетыпа. Дадзеныя характары - прыклад несвядомых паводзін чалавека (чалавецтва) ў канкрэтных жыццёвых сітуацыях. Пакуль ёсць сілы - чалавек, як можа, змагаецца за выжыванне; калі наступае момант расчаравання і бяссілля - ён аддаецца волі лёсу, становіцца філосафам, назіральнікам.

Такім чынам, аналіз архетыпаў, рэканструяваных у разгледжаных творах М. Гарэцкага, не толькі і не столькі дапамагае расчытаць характар эпохі, колькі дазваляе глыбей зразумець псіхалагічны стан пісьменніка, яго прыхаванае еgо, што з'яўляецца каштоўным матэрыялам для разумення класічнай літаратурнай спадчыны ў цэлым.

\section{I T E R A T U R A}

S. Błuwbierg, Rieligioznyj discurs, «Socyalnaja politika i socyołogija» № 2, 2007 [С. Блувберг, Религиозный дискурс, "Социальная политика и социология" 2007, № 2].

P. Wasiuczenka, Ad tekstu da chranatopa, Minsk 2009 [П. Васючэнка, Ад тэксту да хранатопа, Мінск 2009].

M. Garecki, Wybranyja twory, Minsk 2009 [М. Гарэцкі, Выъбраныля творы, Мінск 2009].

M. Garecki, Twory: Dzwie duszy: Apowiesc'. Apawiadanni. Żartauliwy Pisarewicz: P'jesa. Eitaraturna krytyka i pubicystyka, Minsk 1990 [M. Гарэцкі, Tворы: Дзве душы: Аповесиь. Апавяданні. Жартаўлівь Пісарэвіч: П'еса. Літаратурная крытыка і пубічыстылка, Мінск 1990].

17 К. Юнг, Бог и бессознательное, Москва 1998, с. 299. 
M. Lipowieckij, Trikstier $i$ “zakrytoje obszczestwo", NŁO 2009, № 100, [online], http s://magazines.gorky.media/nlo/2009/6/trikster-i-zakrytoe-obshhestvo.html, data dostupu [04.04.2020] [М. Липовецкий, Трикстер и "закрыттое общество", НЛО 2009, № 100 [online], https://magazines.gorky.media/nlo/ 2009/6/trikster-i-zakrytoe-obshhestvo.html, [доступ: 04.04.2020].

Ju. Łotman, W szkole poeticzeskogo słowa, Moskwa 1988 [Ю. Лотман, B школе поэтического слова, Москва 1988].

Ju. Łotman, Istorija i tipotogija russkoj kultury, Sankt-Pietierburg 2002 [Ю. Лотман, История и типология русской культурьь, Санкт-Петербург 2002].

Je. Mieletinskij, Ot mifa $k$ litieraturie. Kurs lekcyj Tieorija mifa i istoriczeskaja poetika, Moskwa 2000 [Е. Мелетинский, Om мифа к литературе. Курс лекций Теория мифа и историческая поэтика, Москва 2000].

Je. Mieletinskij, Mify narodow mira: encyklopiedija: w 2 t., Moskwa 1994 [E. Meлетинский, Мифы народов мира: энциклопедия: в 2 т., Москва 1994].

K. Jung, Bog i biessoznatielnoje, Moskwa 1998 [K. Юнг, Бог и бессознательное, Москва 1998].

T. Szamiakina, Mifałogiia i bielaruskaja titaratura: narysyi ese, Minsk 2008 [T. Шамякіна, Міфалогія $і$ беларуская літаратура: нарысьь $і$ эсэ, Мінск 2008].

$$
\text { РЭ } ३ \text { М Э }
$$

\section{РЭКАНСТРУКЦЫЯ АРХЕТЫПА ЯК СРОДАК СПАСЦКЖЭННЯ АЎТАРСКАГА НЕСВЯДОМАГА (НА ПРЫКЛАДЗЕ ТВОРАЎ МАКСІМА ГАРЭЦКАГА ВЯЦКАГА ПЕРЫЯДУ)}

У артыкуле рэканструіруюцца архетыпы «раскаянага грэшніка» і «трыкстэра» у выбраных творах Максіма Гарэцкага Вяцкага перыяду. Падкрэсліваецца, што ў рамках унутрылітаратурнай прасторы аналіз вобразаў з канатацыямі архетыпаў у творах М. Гарэцкага дазваляе выявіць псіхалагічны стан пісьменніка, яго затоенае еgо, што з'яўляецца каштоўным матэрыяалам для разумення літаратурнай спадчыны як беларускага класіка, так і мастацкай літаратуры у целым. Даказваецца, што пісьменнік не мадэліраваў учынкі літаратурных персанажаў твора свядома, падстройваючыся пад стэрэатып паводзін згодна архетыпу. Увага акцэнтуецца і на адсутнасці архетыпічных сюжэтаў. Актуалізацыя архетыпаў у згаданых творах носіць несвядомы характер.

Ключавыя словы: архетып, наратар, рэлігіозны дыскурс, міф, несвядомае. 
S T R E S Z C Z E N I E

\title{
REKONSTRUKCJA ARCHETYPU JAKO ŚRODKA POJMOWANIA AUTORSKIEJ NIEŚWIADOMOŚCI (NA PRZYKEADZIE DZIE€ M. GORECKIEGO Z OKRESU WIACKIEGO)
}

Artykuł rekonstruuje archetypy „pokutujaccego grzesznika” i „trickstera” w wybranych dziełach M. Goreckiego z okresu wiackiego. Autor artykułu podkreśla, że w ramach przestrzeni wewnątrzliterackiej analiza obrazów z konotacjami archetypów w twórczości M. Goreckiego ujawnia stan psychiczny pisarza, jego ukryte ego, które jest cennym materiałem do zrozumienia dziedzictwa literackiego zarówno białoruskiego klasyka, jak i fikcji w ogóle. Autor dowodzi, że pisarz nie modelował świadomie działań literackich bohaterów utworu, dostosowując się do stereotypu zachowania zgodnie z archetypem. Uwagę zwraca również brak wątków archetypowych. Aktualność archetypów w tych dziełach jest nieświadoma.

Słowa kluczowe: archetyp, narrator, dyskurs religijny, mit, nieświadomość.

\author{
S U M M A R Y
}

RECONSTRUCTION OF THE ARCHETYPE AS A MEANS OF COMPREHENDING THE AUTHOR'S UNCONSCIOUSNESS (ON THE EXAMPLE

OF M. GORETSKY'S WORKS OF THE VYATKA PERIOD)

The article reconstructs the archetypes of the "penitent sinner" and "trickster" in the selected works of M. Goretsky of the Vyatka period. It is emphasized that within the framework of the intra-literary space, the analysis of images with connotations of archetypes in the works of M. Goretsky reveals the psychological state of the writer, his hidden ego, which is a valuable material for understanding the literary heritage of both the Belarusian classic and fiction in general. It is proved that the writer did not model the actions of the literary characters of the work consciously, adjusting to the stereotype of behavior according to the archetype. The attention is also focused on the absence of archetypal plots. The actualization of archetypes is unconscious.

Key words: archetype, narator, religious discourse, myth, unconscious. 